\title{
Trametinib modulates cancer multidrug resistance by targeting ABCB1 transporter
}

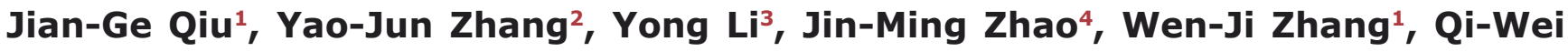 \\ Jiang ${ }^{1}$, Xiao-Long Mei $^{1}$, You-Qiu Xue ${ }^{1}$, Wu-Ming Qin ${ }^{1}$, Yang Yang ${ }^{1}$, Di-Wei Zheng ${ }^{1}$, \\ Yao Chen ${ }^{1}$, Meng-Ning Wei ${ }^{1}$ and Zhi Shi ${ }^{1}$ \\ ${ }^{1}$ Department of Cell Biology and Institute of Biomedicine, College of Life Science and Technology, Jinan University, National \\ Engineering Research Center of Genetic Medicine, Guangdong Provincial Key Laboratory of Bioengineering Medicine, \\ Guangzhou, Guangdong, China \\ 2 Department of Hepatobiliary Surgery, Cancer Center, Sun Yat-Sen University, Guangzhou, Guangdong, China \\ ${ }^{3}$ Department of Gastrointertinal Surgery and General Surgery, Guangdong General Hospital, Guangdong Academy of Medical \\ Sciences, Guangzhou, Guangdong, China \\ ${ }^{4}$ Department of Thoracic Surgery, The Sixth Affiliated Hospital, Sun Yat-sen University, Guangzhou, Guangdong, China \\ Correspondence to: Zhi Shi, email: tshizhi@jnu.edu.cn
}

Keywords: trametinib, multidrug resistance, $A B C B 1$, chemotherapy

Received: February 09, $2015 \quad$ Accepted: March 10, $2015 \quad$ Published: April 14, 2015

This is an open-access article distributed under the terms of the Creative Commons Attribution License, which permits unrestricted use, distribution, and reproduction in any medium, provided the original author and source are credited.

\section{ABSTRACT}

Overexpression of adenine triphosphate (ATP)-binding cassette (ABC) transporters is one of the main reasons of multidrug resistance (MDR) in cancer cells. Trametinib, a novel specific small-molecule mitogen-activated extracellular signalregulated kinase (MEK) inhibitor, is currently used for the treatment of melanoma in clinic. In this study, we investigated the effect of trametinib on MDR mediated by $A B C$ transporters. Trametinib significantly potentiated the effects of two ABCB1 substrates vincristine and doxorubicin on inhibition of growth, arrest of cell cycle and induction of apoptosis in cancer cells overexpressed $A B C B 1$, but not $A B C C 1$ and ABCG2. Furthermore, trametinib did not alter the sensitivity of non-ABCB1 substrate cisplatin. Mechanistically, trametinib potently blocked the drug-efflux activity of $A B C B 1$ to increase the intracellular accumulation of rhodamine 123 and doxorubicin and stimulates the ATPase of ABCB1 without alteration of the expression of ABCB1. Importantly, trametinib remarkably enhanced the effect of vincristine against the

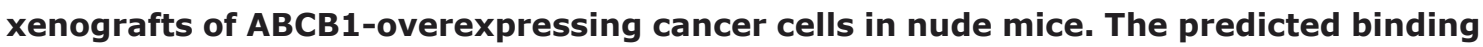
mode showed the hydrophobic interactions of trametinib within the large drug binding cavity of $A B C B 1$. Consequently, our findings may have important implications for use of trametinib in combination therapy for cancer treatment.

\section{INTRODUCTION}

Cancer cells with multidrug resistance (MDR) to chemotherapeutic drugs significantly reduces the efficacy of cancer chemotherapy [1]. Various mechanisms are involved in the MDR of cancer, including induction of the antiapoptotic machinery, increase of the intracellular drug efflux, reduce of the drug uptake, and so on [2]. Overexpressing the adenine triphosphate (ATP)-binding cassette (ABC) transporters, particularly ABCB1 (MDR1/ P-glycoprotein), ABCC1 (MRP1) and ABCG2 (BCRP), are one of most common reasons to result in MDR in cancer cells [3-6]. For instance, ABCB1 can transport multiple types of chemotherapeutic drugs out of cells, such as the taxanes (paclitaxel, docetaxel), epipodophyllotoxins (etoposide), vinca alkaloids (vincristine, vinblastine), and anthracyclines (doxorubicin, epirubicin), and this process is coupled to the energy of ATP hydrolysis on the ATPase domain [7-10]. Therefore, inhibition of these transporters will restore the sensitivity of MDR cancer cells to chemotherapeutic agents, and may permit a successful chemotherapy to patients with MDR cancer [11, 12].

Trametinib (Mekinist, GSK1120212) is a novel selective and highly potent small molecular inhibitor 
of mitogen-activated extracellular signal-regulated kinase (MEK) with a half maximum $\mathrm{IC}_{50}$ of 0.7-14.9 $\mathrm{nM}$ for MEK1 and MEK2, which are the central hubs of mitogen-activated protein kinase (MAPK) pathway to control oncogenic cell proliferation, survival, invasion, angiogenesis and death, etc [13-15]. The preclinical experiments demonstrated trametinib had broad anticancer activity in multiple cancer models by inducing cell cycle arrest, apoptosis and growth inhibition in vitro and in vivo, especially in cancer cells with activating mutations of BRAF and KRAS in the MAPK pathway [14]. In a multicentre phase 1 dose-escalation trial of 206 patients with advanced solid tumors to assesse the safety, pharmacokinetics, pharmacodynamics, and efficacy data of trametinib, the maximum tolerated dose was $3 \mathrm{mg}$ once daily, the effective half-life was around 4 days, and active pathway inhibition and clinical activity were recorded [16]. Another phase 1 study in 97 patients with advanced melanoma showed substantial clinical activity of trametinib in melanoma [17]. The following open-label, two-stage, phase II trial with two cohorts in patients with metastatic BRAF-mutant melanoma observed significant clinical activity of trametinib with the most common side effects including skin-related toxicity, peripheral edema, nausea, pruritis, diarrhea, and fatigue [18]. In the phase 3 trial in 322 patients who had metastatic melanoma with V600E or V600K BRAF mutation, trametinib improved progression-free survival and overall survival times in comparesion with dacarbazine or paclitaxel [19]. Based on these data, trametinib was approved by FDA as monotherapy for use in patients with V600E or V600K BRAF mutated unresectable or metastatic melanoma in May 2013. Moreover, FDA granted accelerated approval to the combination therapy of trametinib with a BRAF inhibitor dabrafenib in the aforementioned patients in January 2014, based on the improved median progressionfree survival and response rate shown with combination therapy [20]. Currently, investigation of trametinib in combination with other chemotherapeutical agents for the treatment of multiple types of cancers is ongoing. In this study, we demonstrate that trametinib significantly sensitizes ABCB1-medidated MDR cancer cells to chemotherapeutic agents in vitro and in vivo by directly antagonizing the drug-efflux activity of ABCB1.

\section{RESULTS}

\section{Trametinib enhances the sensitivity of ABCB1- substrate chemotherapeutic agents in the ABCB1- overexpressing cells}

To investigate the effects of trametinib on ABCB1mediated MDR in cancer cells, we firstly examined the cytotoxicity of trametinib in two ABCB1-overexpressing cells $\mathrm{KB}_{\mathrm{V} 200}$ and $\mathrm{MCF}-7 / \mathrm{ADR}$ and their parental cells $\mathrm{KB}$ and MCF-7 by MTT assay. As shown in Figure $1 \mathrm{~B}$, over $80 \%$ of all four cells were viable after treated with trametinib at $10 \mu \mathrm{M}$, indicating that this dose could be used as the highest concentration to explore the ability of trametinib on enhancing the sensitivity of chemotherapeutic drugs in ABCB1-overexpressing MDR cancer cells. We then tested the cytotoxicity of combination of trametinib with two ABCB1 substrates vincristine and doxorubicin and one non-ABCB1 substrate cisplatin at the various concentrations. The summary $\mathrm{IC}_{50}$ values and survival curves were shown in Table 1 and Figure $1 \mathrm{C}$. Compared with $\mathrm{KB}$ and $\mathrm{MCF}-7$ cells, $\mathrm{KB}_{\mathrm{V} 200}$ and MCF-7/ADR cells exhibited high resistance to vincristine and doxorubicin but not to cisplatin. Trametinib dose-dependently decreased the $\mathrm{IC}_{50}$ values of vincristine and doxorubicin in both $\mathrm{KB}_{\mathrm{V} 200}$ and MCF-7/ ADR cells but not in KB and MCF-7 cells, which was similar to the effects of the known ABCB1 inhibitor verapamil. Furthermore, trametinib did not significantly alter the cytotoxicity of cisplatin in either MDR or parental cells. In addition, we also detected the effects of trametinib on $\mathrm{ABCC} 1$ and $\mathrm{ABCG} 2-$ mediated MDR, and found that trametinib at $10 \mu \mathrm{M}$ did not reduce the resistances of vincristine (also the substrate of $\mathrm{ABCC} 1$ ) in $\mathrm{ABCC} 1$ overexpressing cells KB-CV60 and doxorubicin (also the substrate of ABCG2) in ABCG2-overexpressing cells S1M1-80 (Supplementary Figure 1). Together, our results demonstrated that trametinib significantly enhanced the sensitivity of ABCB1-substrate chemotherapeutic agents in the $\mathrm{ABCB} 1$-overexpressing cells, suggesting trametinib is able to antagonize ABCB1-mediated cancer MDR in vitro.

\section{Trametinib in combination with ABCB1-substrate chemotherapeutic agents induces cell cycle arrest

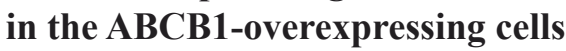

To evaluate the effects of trametinib in combination with chemotherapeutic agents in the ABCB1overexpressing cells, cell cycle distribution and the related proteins were detected by FCM and Western blot, respectively. As shown in Figure 2A and 2B, co-treatment with trametinib and vincristine significantly increased the cell population of sub-G1 and G2/M phase and the levels of G2/M-phase dominant proteins cyclin B1 and cyclin-dependent kinase inhibitor p21 in comparison with trametinib or vincristine alone treatment in $\mathrm{KB}_{\mathrm{V} 200}$ cells but not in KB cells. Similarly, co-treatment with trametinib and doxorubicin significantly increased the cell population of sub-G1 and G2/M phase and the protein levels of cyclin $\mathrm{B} 1$ and $\mathrm{p} 21$ in comparison with trametinib or doxorubicin alone treatment in MCF-7/ADR cells but not in MCF-7 cells. 
A<smiles></smiles>

C

KB
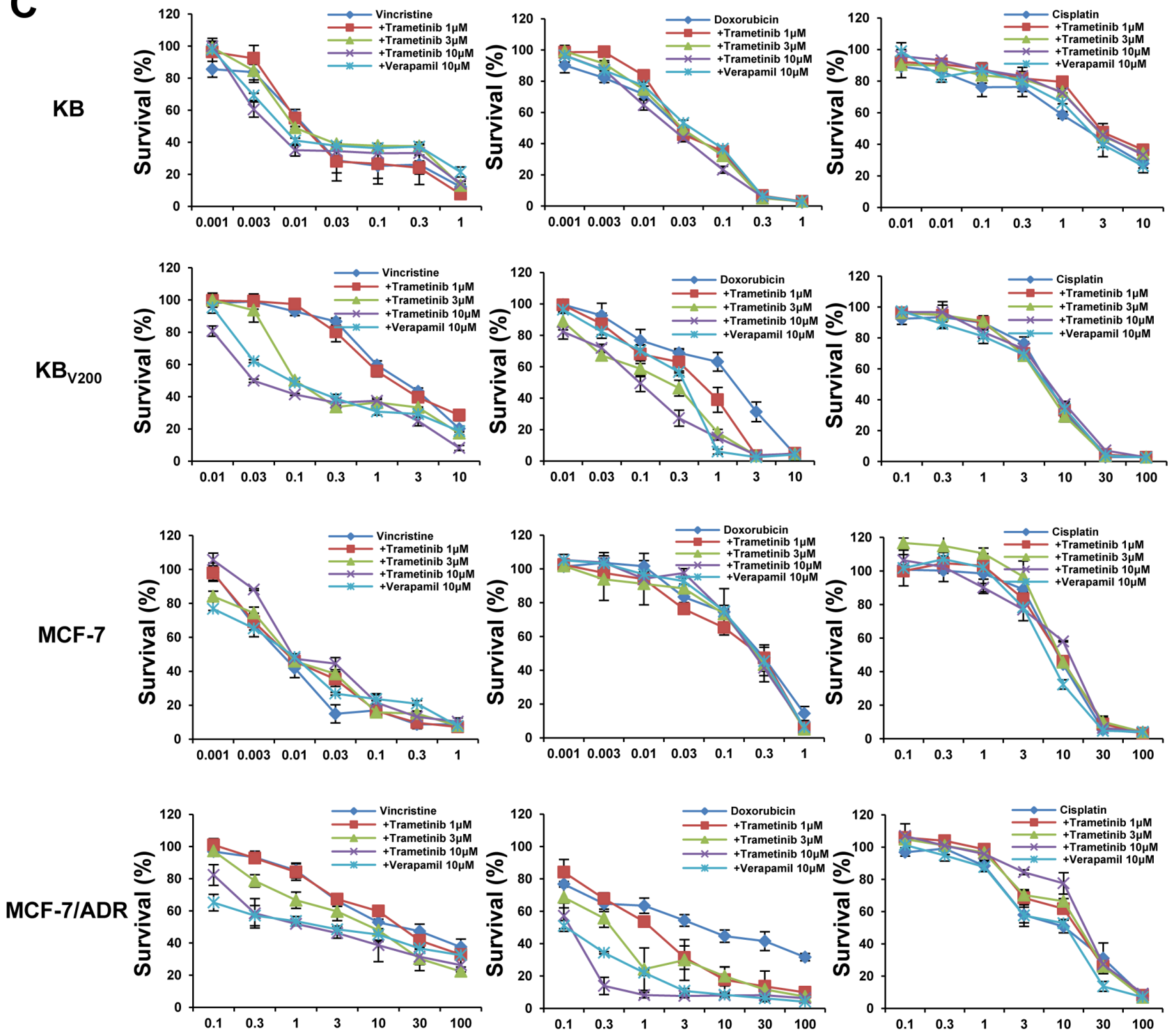

Vincristine $(\mu \mathrm{M})$
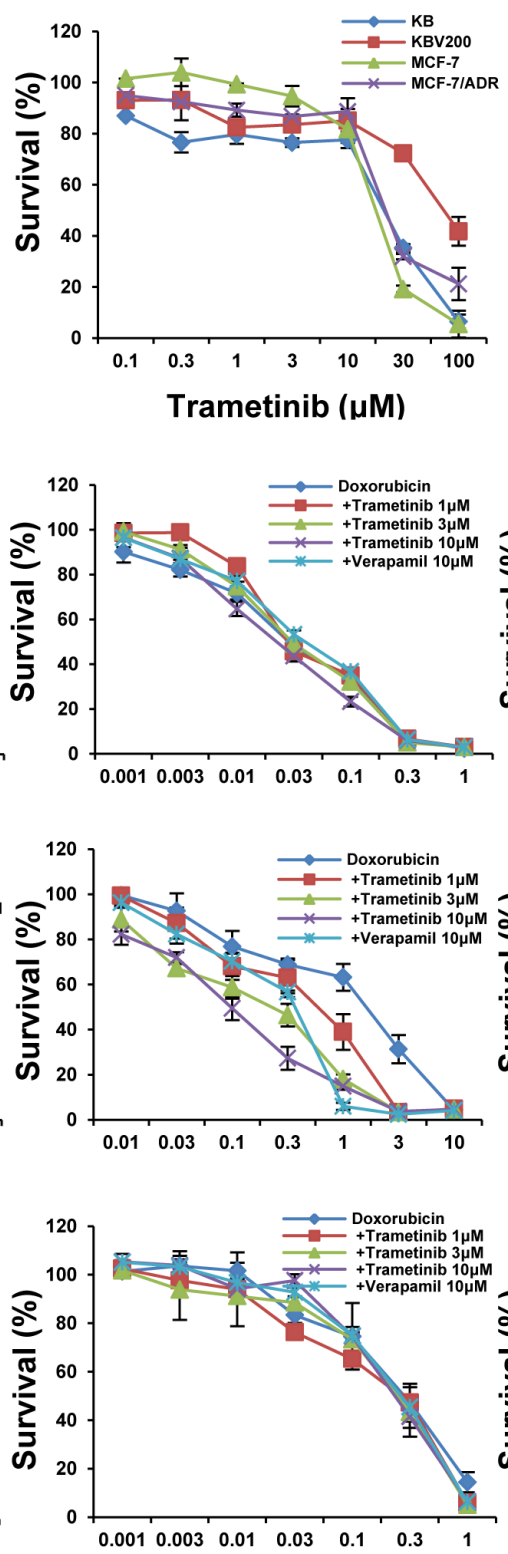

Trametinib ( $\mu \mathrm{M})$

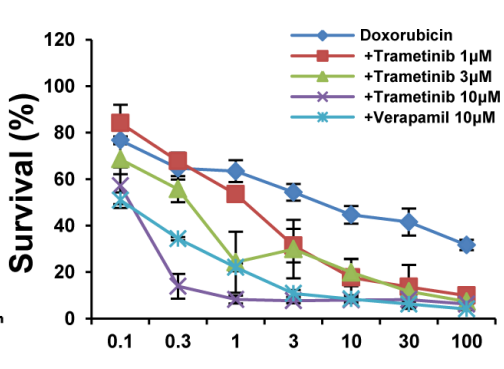

Doxorubicin $(\mu \mathrm{M})$

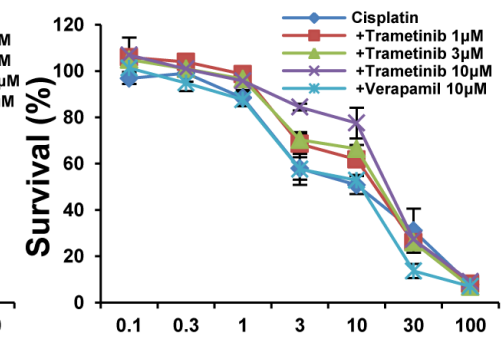

Cisplatin $(\mu \mathrm{M})$

Figure 1: Trametinib enhances the sensitivity of $\mathrm{ABCB} 1$-substrate chemotherapeutic agents in the ABCB1overexpressing cells. Cells were treated with the indicated concentrations of trametinib $(\mathbf{A})$ or other agents for $72 \mathrm{~h}$, and cell survival was measured by MTT assay. The representative growth curve of $\mathrm{KB}, \mathrm{KB}_{\mathrm{V} 200}$, MCF-7 and MCF-7/ADR cells treated with trametinib alone (B) or in combination with vincristine, doxorubicin and cisplatin (C) are shown. 
Table 1: Summary of the effects of trametinib on enhancing the sensitivity of vincristine, doxorubicin and cisplatin in cancer cells.

\begin{tabular}{|c|c|c|c|c|}
\hline \multirow{2}{*}{ Compounds $(\mu \mathrm{M})$} & \multicolumn{4}{|c|}{$\mathrm{IC}_{50} \pm \mathrm{SD}$ (fold-reversal) } \\
\hline & KB & $\mathrm{KB}_{\mathrm{v} 200}$ & MCF-7 & MCF-7/ADR \\
\hline Vincristine & $0.020 \pm 0.007(1.000)$ & $2.044 \pm 0.193(1.000)$ & $0.012 \pm 0.006(1.000)$ & $19.474 \pm 1.183(1.000)$ \\
\hline +Trametinib $1 \mu \mathrm{M}$ & $0.015 \pm 0.002(1.333)$ & $1.745 \pm 0.087(1.171)$ & $0.014 \pm 0.007(0.857)$ & $20.080 \pm 0.974(0.970)$ \\
\hline+ Trametinib $3 \mu \mathrm{M}$ & $0.014 \pm 0.006(1.429)$ & $0.166 \pm 0.093(12.313)^{*}$ & $0.013 \pm 0.006(0.923)$ & $8.960 \pm 0.294(2.173)^{*}$ \\
\hline +Trametinib $10 \mu \mathrm{M}$ & $0.012 \pm 0.009(1.667)$ & $0.042 \pm 0.018(48.667)^{* *}$ & $0.012 \pm 0.003(1.000)$ & $2.209 \pm 0.774(8.816)^{*}$ \\
\hline +Verapamil $10 \mu \mathrm{M}$ & $0.009 \pm 0.001(2.222)$ & $0.083 \pm 0.015(24.627)^{* *}$ & $0.013 \pm 0.005(0.923)$ & $2.102 \pm 0.437(9.265)^{*}$ \\
\hline Doxorubicin & $0.034 \pm 0.008(1.000)$ & $1.662 \pm 0.235(1.000)$ & $0.254 \pm 0.037(1.000)$ & $4.749 \pm 1.957(1.000)$ \\
\hline +Trametinib $1 \mu \mathrm{M}$ & $0.031 \pm 0.004(1.097)$ & $0.386 \pm 0.413(4.306)^{*}$ & $0.231 \pm 0.055(1.100)$ & $1.113 \pm 0.086(4.267)^{*}$ \\
\hline +Trametinib $3 \mu \mathrm{M}$ ) & $0.028 \pm 0.002(1.214)$ & $0.250 \pm 0.012(6.648)^{*}$ & $0.199 \pm 0.081(1.276)$ & $0.517 \pm 0.181(9.186)^{*}$ \\
\hline +Trametinib $10 \mu \mathrm{M}$ & $0.024 \pm 0.001(1.417)$ & $0.096 \pm 0.003(17.313)^{* *}$ & $0.185 \pm 0.090(1.373)$ & $0.234 \pm 0.143(20.295)^{* *}$ \\
\hline +Verapamil $10 \mu \mathrm{M}$ & $0.046 \pm 0.003(0.739)$ & $0.232 \pm 0.226(7.164)^{*}$ & $0.260 \pm 0.013(0.977)$ & $0.145 \pm 0.047(32.752) * *$ \\
\hline Cisplatin & $2.357 \pm 0.402(1.000)$ & $6.838 \pm 0.403(1.000)$ & $7.992 \pm 1.588(1.000)$ & $11.229 \pm 0.670(1.000)$ \\
\hline +Trametinib $1 \mu \mathrm{M}$ & $2.863 \pm 0.021(0.823)$ & $6.221 \pm 0.823(1.099)$ & $8.789 \pm 0.692(0.909)$ & $21.168 \pm 6.503(0.530)$ \\
\hline+ Trametinib $3 \mu \mathrm{M}$ & $2.390 \pm 0.367(0.986)$ & $5.481 \pm 1.174(1.248)$ & $9.013 \pm 0.541(0.887)$ & $23.884 \pm 8.149(0.470)$ \\
\hline +Trametinib $10 \mu \mathrm{M}$ & $2.34 \pm 0.4789(1.007)$ & $6.317 \pm 1.634(1.082)$ & $12.064 \pm 1.495(0.660)$ & $22.664 \pm 2.426(0.0 .495)$ \\
\hline +Verapamil $10 \mu \mathrm{M}$ & $2.459 \pm 0.329(0.959)$ & $6.606 \pm 0.321(1.035)$ & $7.560 \pm 0.365(1.057)$ & $11.711 \pm 0.397(0.959)$ \\
\hline
\end{tabular}

The fold-reversal value was calculated by dividing the $\mathrm{IC}_{50}$ for cells with the anticancer in the absence of trametinib or verapamil by that obtained in the presence of trametinib or verapamil. $* P<0.05$ and $* * P<0.01$ vs. corresponding control ( $\mathrm{n}=3$ ).

\section{Trametinib in combination with ABCB1-substrate chemotherapeutic agents induces apoptosis in the ABCB1-overexpressing cells}

To further estimate the effects of trametinib in combination with chemotherapeutic agents in the ABCB1-overexpressing cells, cell apoptosis and the related proteins were also detected by FCM and Western blot, respectively. As shown in Figure 3A and 3B, cotreatment with trametinib and vincristine dramatically enhanced the early apoptosis (Annexin $\mathrm{V}+/ \mathrm{PI}-$ ) and late apoptosis (Annexin $\mathrm{V}+/ \mathrm{PI}+$ ) and the protein levels of apoptotic marker cleaved PARP (C-PARP) in comparison with trametinib or vincristine alone treatment in $\mathrm{KB}_{\mathrm{V} 200}$ cells but not in KB cells. Similarly, co-treatment with trametinib and doxorubicin dramatically enhanced the apoptosis and the protein levels of C-PARP in comparison with trametinib or doxorubicin alone treatment in MCF-7/ ADR cells but not in MCF-7 cells. In addition, the protein levels of phosphorylated ERK (pERK) were completely blocked by trametinib in all four cells.

\section{Trametinib in combination with vincristine inhibits the growth of $\mathrm{KB}_{\mathrm{v} 200}$ xenografts in nude mice}

To confirm the ability of trametinib antagonizing $\mathrm{ABCB} 1$-mediated cancer MDR in vivo, $\mathrm{KB}_{\mathrm{V} 200}$ xenografts models were generated in the nude mice. As shown in Figure $4 \mathrm{~A}-4 \mathrm{C}$, treatment with trametinib or vincristine alone did not inhibit the growth of $\mathrm{KB}_{\mathrm{V} 200}$ xenografts, but co-treatment with trametinib and vincristine obviously inhibited the growth of $\mathrm{KB}_{\mathrm{V} 200}$ xenografts with the inhibition ratio of $63.29 \%$ (Figure 4E). Furthermore, there was no loss of mice body weight in the combination group, suggesting that the combination regimen at the indicated dose did not cause toxicity in mice (Figure 4D). Additionally, the results of immunohistochemical staining showed that the percentage of C-PARP positive cells in $\mathrm{KB}_{\mathrm{V} 200}$ xenografts was significantly increased in the combination group in comparison with vincristine or trametinib alone group (Figure 4F).

\section{Trametinib increases the intercellular accumulation of rhodamine 123 and doxorubicin

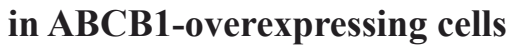

To examine whether trametinib antagonizing ABCB1-mediated cancer MDR is owing to inhibition of the transporter activity of $\mathrm{ABCB} 1$, we measured the intracellular levels of two $\mathrm{ABCB} 1$ substrates rhodamine 123 and doxorubicin in the presence or absence of trametinib. As shown in Figure $5 \mathrm{~A}$ and $5 \mathrm{~B}$, the intracellular levels of both rhodamine 123 and doxorubicin in $\mathrm{KB}_{\mathrm{V} 200}$ and MCF-7/ADR cells were significantly lower than those in $\mathrm{KB}$ and MCF-7 cells, respectively. Trametinib dose-dependently increased the intracellular levels of rhodamine 123 and doxorubicin in both $\mathrm{KB}_{\mathrm{v} 200}$ and MCF-7/ADR cells but not in KB and MCF-7 cells, which was equal to the effects of verapamil, suggesting that trametinib is able to directly inhibiting the drug efflux function of $\mathrm{ABCB} 1$. 
A
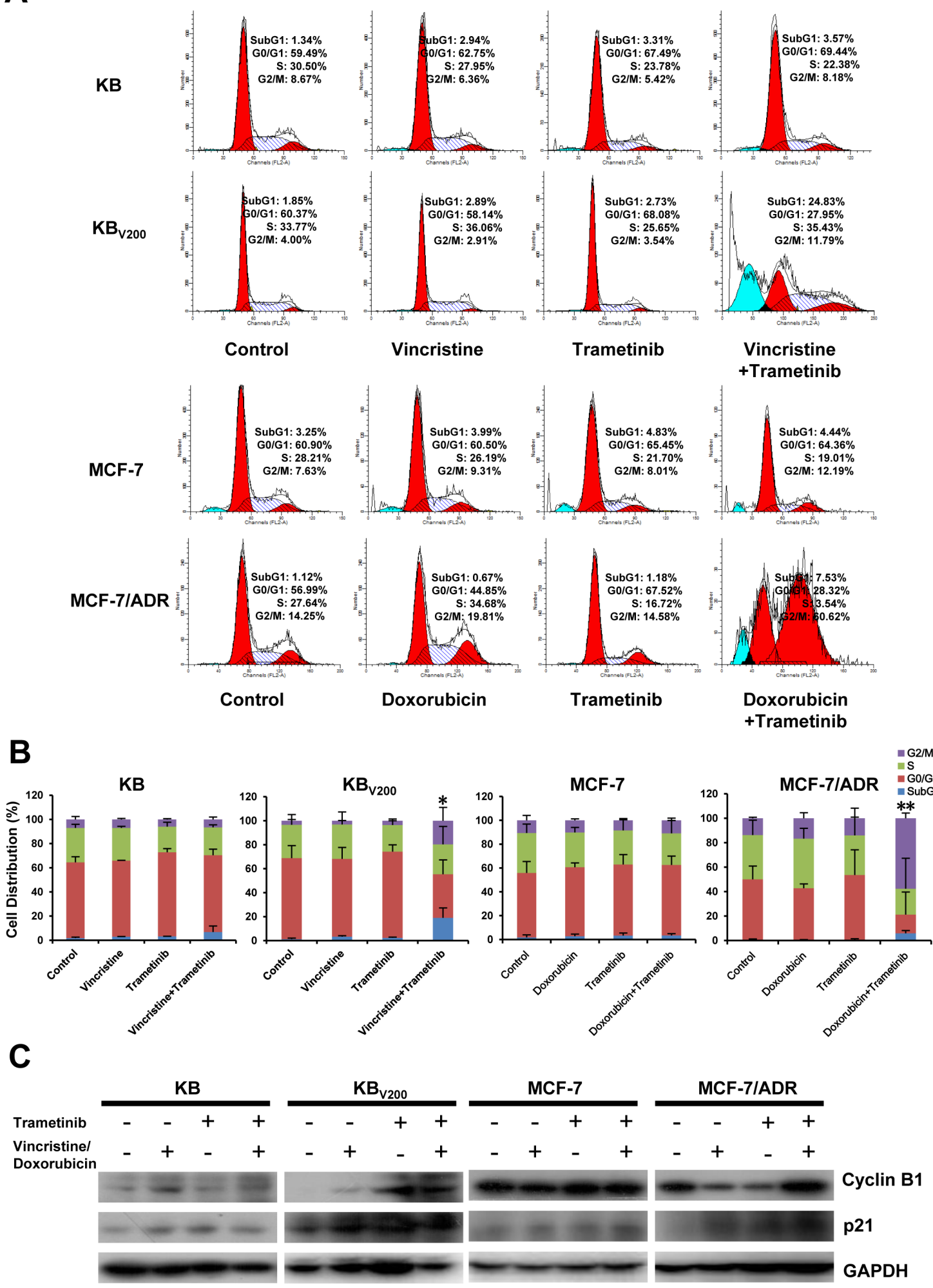

Figure 2: Trametinib in combination with $\mathrm{ABCB} 1$-substrate chemotherapeutic agents induces cell cycle arrest in the ABCB1-overexpressing cells. Cells were treated with the indicated agents for 48 hours, and the distribution of cell cycle was detected by FCM with PI staining. The protein expression was examined by Western blot after lysing cells, and GAPDH was used as loading control. The concentrations of each agent were used as follow: vincristine $0.03 \mu \mathrm{M}$ in $\mathrm{KB}$ and $0.3 \mu \mathrm{M}$ in $\mathrm{KB}_{\mathrm{V} 200}$, doxorubicin $0.01 \mu \mathrm{M}$ in MCF-7 and $1 \mu \mathrm{M}$ in MCF-7/ADR, trametinib $10 \mu \mathrm{M}$ in all four cells. The representative charts (A), quantified data $(\mathbf{B})$ and Western blot results $(\mathbf{C})$ are shown. ${ }^{*} P<0.05$ and ${ }^{*} P<0.01$ vs. corresponding control $(n=3)$. 

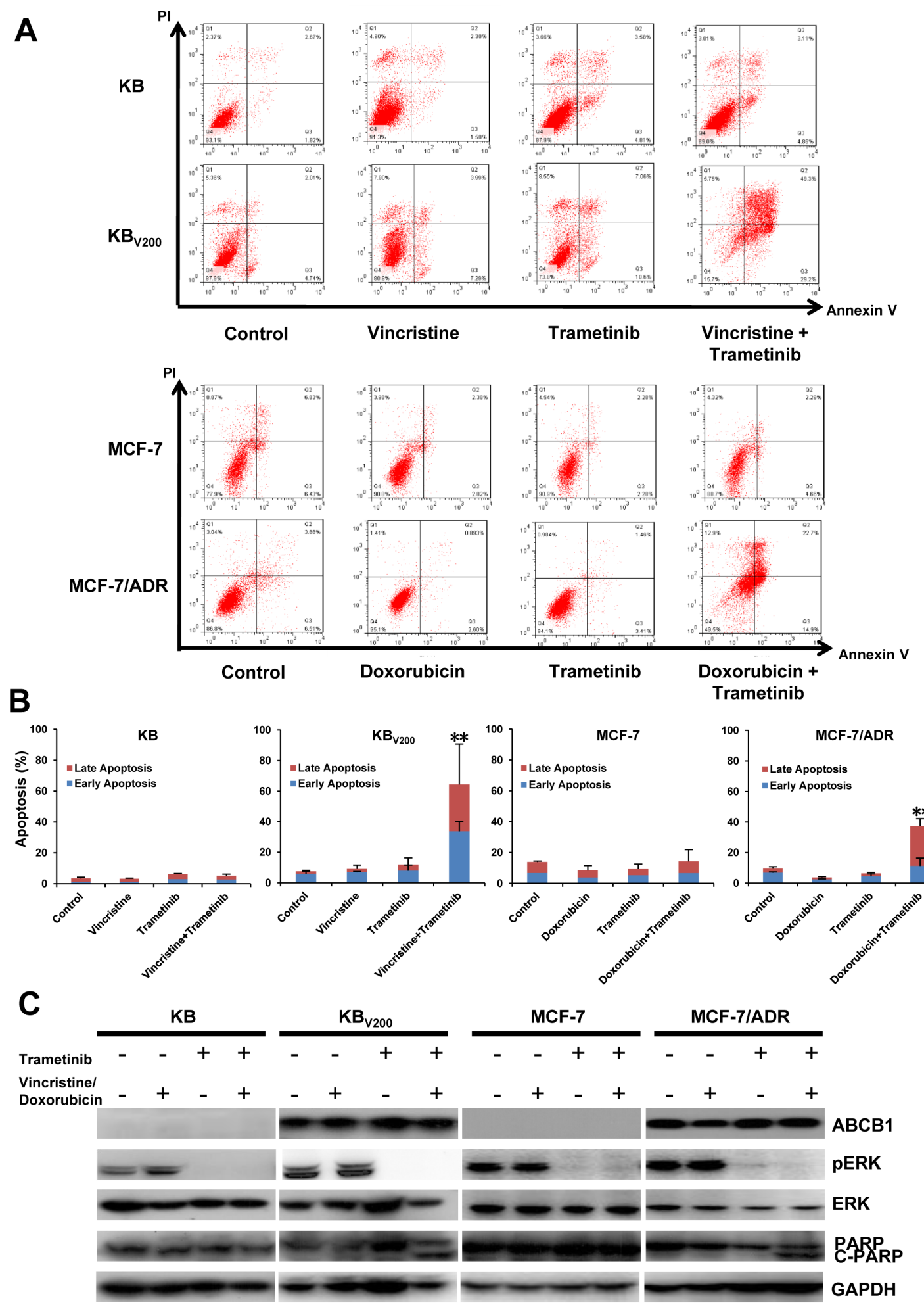

Figure 3: Trametinib in combination with $\mathrm{ABCB1}$-substrate chemotherapeutic agents induces apoptosis in the ABCB1-overexpressing cells. Cells were treated with the indicated agents for 48 hours, and the apoptosis was detected by FCM Annexin V/PI staining. The proportions of Annexin V+/PI- and Annexin V+/PI+ cells indicated the early and late stage of apoptosis. The protein expression was examined by Western blot after lysing cells, and GAPDH was used as loading control. The concentrations of each agent were used as follow: vincristine $0.03 \mu \mathrm{M}$ in $\mathrm{KB}$ and $0.3 \mu \mathrm{M}$ in $\mathrm{KB}_{\mathrm{v} 200}$, doxorubicin $0.01 \mu \mathrm{M}$ in MCF-7 and $1 \mu \mathrm{M}$ in MCF-7/ADR, trametinib $10 \mu \mathrm{M}$ in all four cells. The representative charts (A), quantified data (B) and Western blot results $(\mathbf{C})$ are shown. ${ }^{*} P<0.05$ and $* * P<0.01$ vs. corresponding control $(n=3)$. 
A

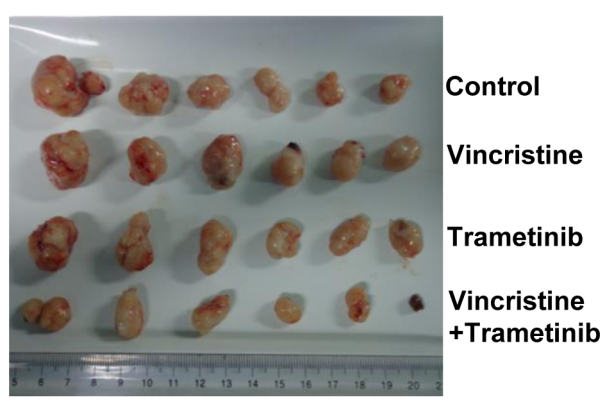

C

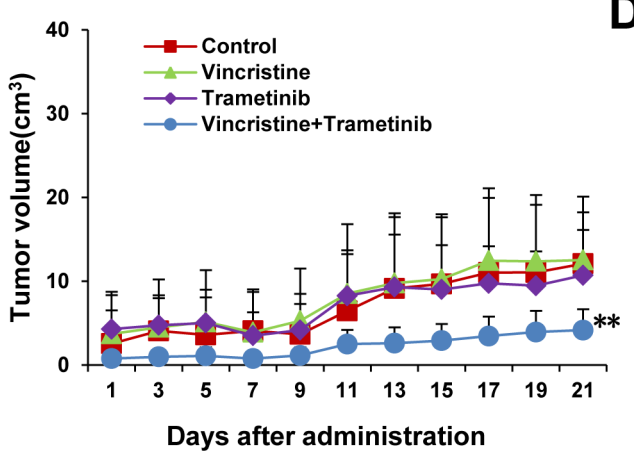

B
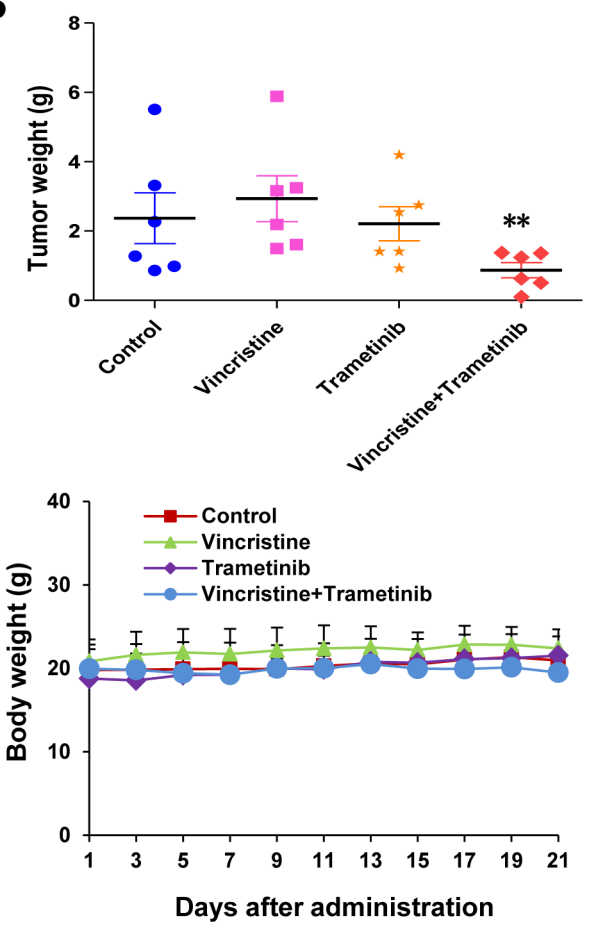

E

Summary of vincristine and trametinib on the growth of $\mathrm{KB}_{\mathrm{v} 200}$ xenografts in nude mice.

\begin{tabular}{ccccccc}
\hline Groups & \multicolumn{2}{c}{ Before Experiment } & \multicolumn{2}{c}{ After Experiment } & Weight of & Inhibition (\%) \\
& Animals & Weight(g) & Animals & Weight(g) & Tumor(g) & \\
Control & 6 & $19.80 \pm 3.05$ & 6 & $20.95 \pm 2.89$ & $2.37 \pm 1.80$ & \\
Vincristine & 6 & $20.84 \pm 2.62$ & 6 & $22.40 \pm 2.28$ & $2.93 \pm 1.63$ & -23.62 \\
Trametinib & 6 & $18.78 \pm 0.72$ & 6 & $21.53 \pm 0.88$ & $2.21 \pm 1.20$ & 6.75 \\
Vincristine+ & 6 & $19.96 \pm 2.34$ & 6 & $19.50 \pm 1.69$ & $0.87 \pm 0.53$ & $63.29 * *$ \\
Trametinib & 6 & & & & & \\
\hline
\end{tabular}

$\mathbf{F}$

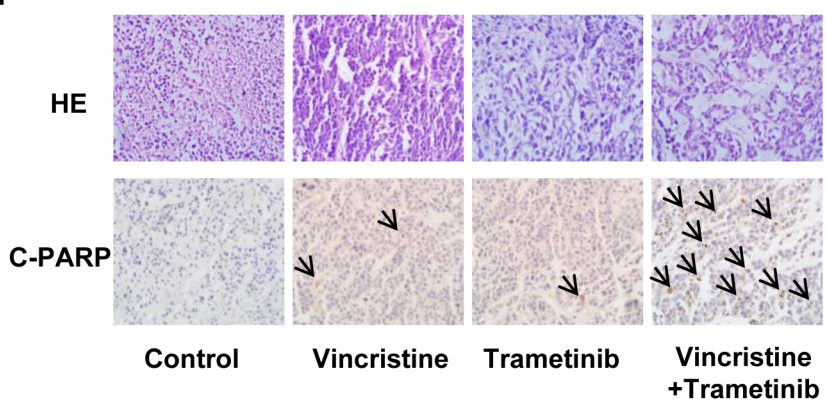

G

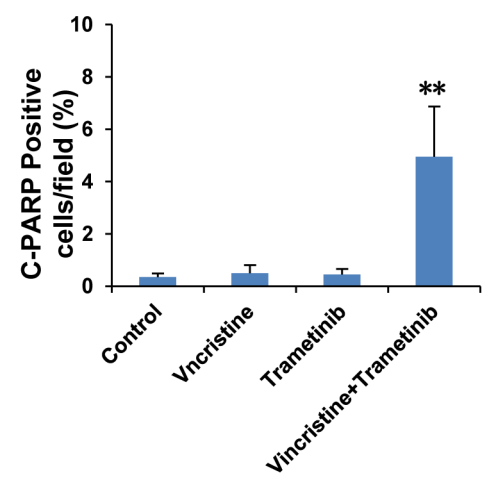

Figure 4: Trametinib in combination with vincristine inhibits the growth of $\mathrm{KB}_{\mathrm{v} 200}{ } \mathrm{xenografts}$ in nude mice. Each mouse was injected subcutaneously with $\mathrm{KB}_{\mathrm{V} 200}$ cells $\left(2 \times 10^{6}\right.$ in $100 \mu \mathrm{l}$ of medium) under the shoulder. When the subcutaneous tumors were approximately $0.3 \times 0.3 \mathrm{~cm}^{2}$ (two perpendicular diameters) in size, mice were randomized into four groups and treated with the following regimens: vehicle alone $(0.9 \%$ saline $)$, vincristine $(0.1 \mathrm{mg} / \mathrm{kg}$, intraperitoneally), trametinib ( $3 \mathrm{mg} / \mathrm{kg}$, orally), and the combination of vincristine with trametinib every two days. The body weights of mice and tumor volume were recorded. The mice were anaesthetized after experiment, and tumor tissue was excised from the mice and weighted. The original tumors (A), tumor weight (B), tumor volume (C), body weight (D) and summary data (E) are shown. The representative H\&E and immunohistochemical C-PARP staining of KB ${ }_{\mathrm{V} 200} \mathrm{xenografts}$ $(\mathbf{F})$, and quantified C-PARP positive cells $(\mathbf{G})$ are also presented. The values presented are the means \pm SD for each group. ${ }^{*} P<0.05$ and $* * P<0.01$ vs. corresponding control $(n=6)$. 

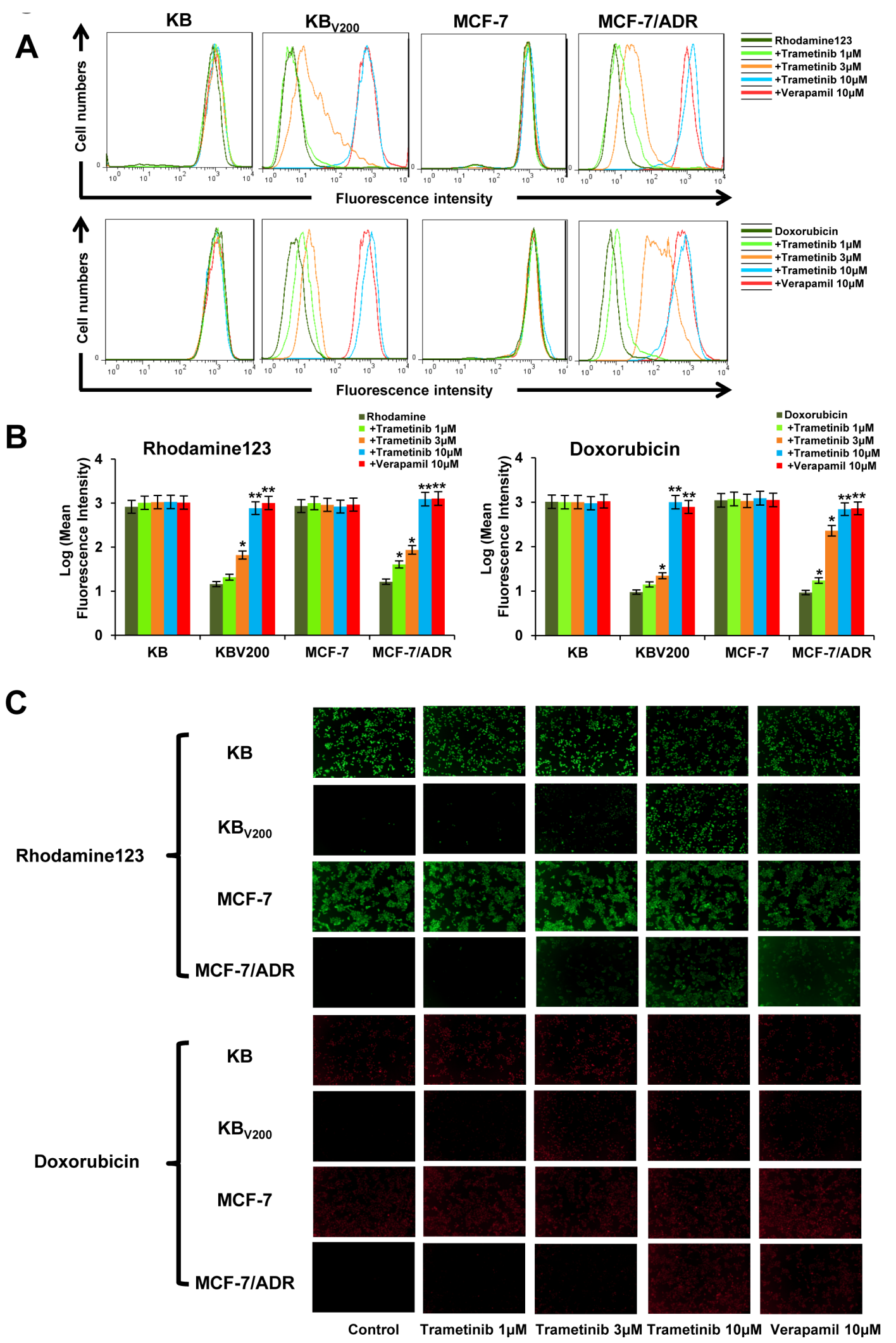

Figure 5: Trametinib increases the intercellular accumulation of rhodamine 123 and doxorubicin in $\mathrm{ABCB} 1-$ overexpressing cells. Cells were incubated with $10 \mu \mathrm{M}$ rhodamin 123 or doxorubicin for another 2 hours at $37^{\circ} \mathrm{C}$ after pre-treated with the indicated concentrations of trametinib and verapemail for 1 hour at $37^{\circ} \mathrm{C}$, measured by FCM and photographed by fluorescent microscope. The representative charts (A), quantified data (B) and graphs $(\mathbf{C})$ are shown. $* P<0.05$ and ${ }^{* *} P<0.01$ vs. corresponding control $(n=3)$. 
Trametinib stimulates the ATPase activity of $A B C B 1$ and does not alert the expression of ABCB1

The transporter function of ABCB1 is coupled to ATP hydrolysis, which is stimulated in the presence of $\mathrm{ABCB} 1$ substrates. To assess the effects of trametinib on the ATPase activity of ABCB1, we detected the ABCB1mediated ATP hydrolysis with various concentrations of trametinib. As shown in Figure 6A, trametinib enhanced the ATPase activity of ABCB1 in the dose-dependent manner with the $\mathrm{EC}_{50}$ value of $1.02 \mu \mathrm{M}$, suggesting that trametinib is the substrate of $\mathrm{ABCB} 1$. In addition, the reversal of ABCB1-mediated MDR can be achieved either by inhibiting its pump activity or by decreasing its expression. To study the effect of trametinib on ABCB1 expression, the protein levels were detected by Western blot after treatment with trametinib at $10 \mu \mathrm{M}$ at the various time points. The results showed that the protein levels of pERK were totally inhibited after trametinib treatment as soon as for $1 \mathrm{~h}$ in all four cells, but the protein levels of $\mathrm{ABCB} 1$ were not altered in $\mathrm{KB}_{\mathrm{V} 200}$ and MCF-7/ADR cells after trametinib treatment even up to 72 hours (Figure 6B). These data indicate that trametinib is able to inhibit the activity of MEK but unable to alter the protein expression of ABCB1.

\section{Model for binding of trametinib to ABCB1}

To understand the mechanism of binding of trametinib to $\mathrm{ABCB} 1$ at a molecular level, docking studies were performed with the crystal structure of mouse Mdr3 as represented by ABCB1-QZ59-RRR, ABCB1-QZ59SSS and ABCB1-verapamil. As shown in Figure 7A and $7 \mathrm{~B}$, the predicted binding mode showed the hydrophobic interactions of trametinib within the large drug binding cavity of ABCB1. Trametinib was stabilized through specific interactions such as hydrogen bonding and nonspecific interactions such as hydrophobic interactions with residues in the drug-binding pocket of $\mathrm{ABCB} 1$. The

\section{A}

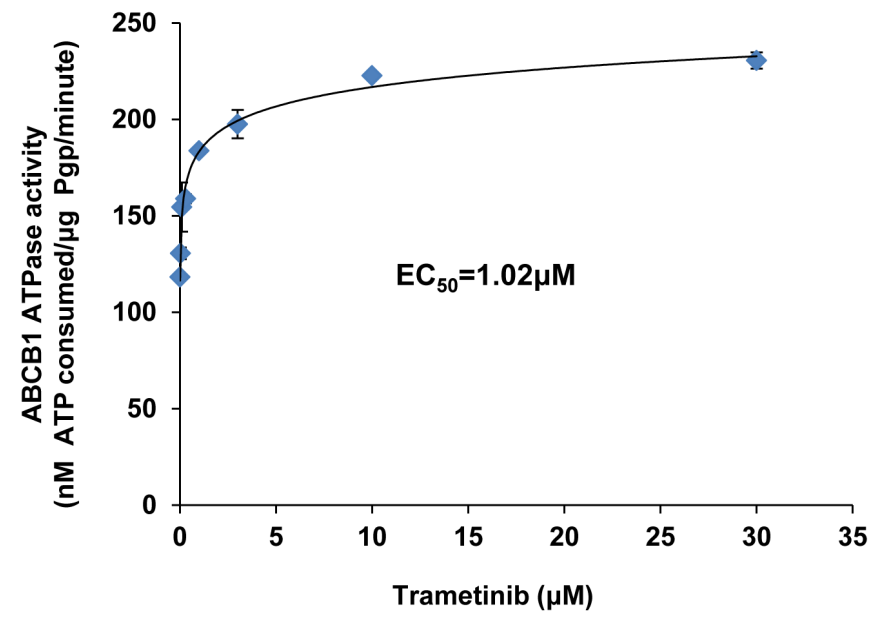

B
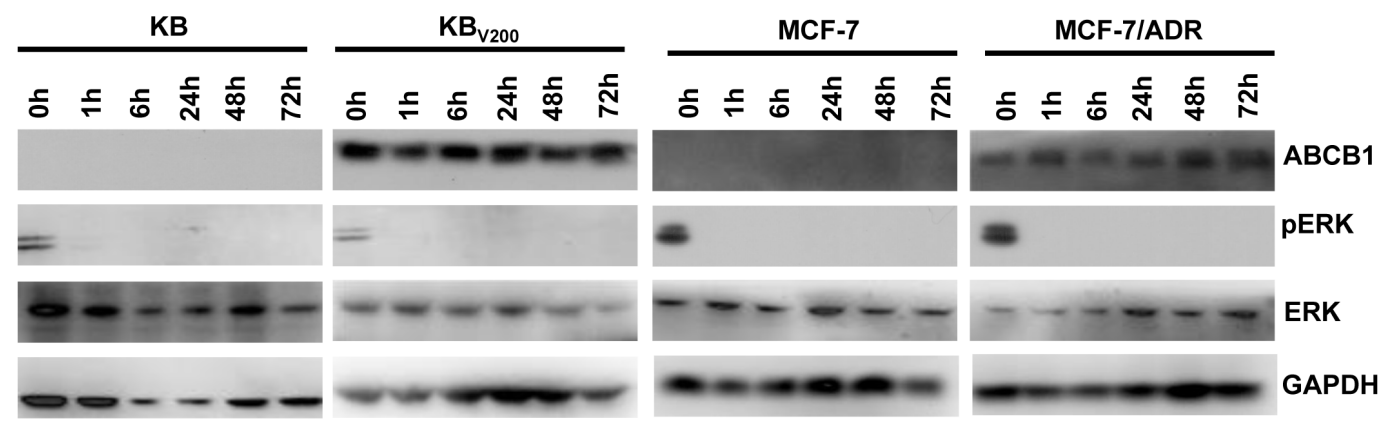

Figure 6: Trametinib stimulates the ATPase activity of ABCB1 and does not alert the expression of ABCB1. The Visensitive ATPase activity of ABCB1 (A) in membrane vesicles was determined with different concentration $(0.01,0.03,0.1,0.3,1,3,10$ and $30 \mu \mathrm{M})$ of trametinib. Cells were treated with trametinib at $10 \mu \mathrm{M}$ for the indicated time points, and the protein expression was examined by Western blot after lysing cells, and GAPDH was used as loading control. The representative Western blot results (B) were shown. 
hydrogen bond acceptor oxygen atom at the position of the carbanyl group showed hydrogen bonding interaction with the side chain of Gln721 (CO-Gln721). The pyrimidine ring and pyridine ring of trametinib interacted with Phe979 through $\pi-\pi$ stacking. The other groups of trametinib might be mainly stabilized through hydrophobic contacts within the large hydrophobic pocket formed by the side chains of Met68, Phe299, Ile302, Tyr303, Tyr306, Phe337, Leu335, Ile336, Phe724, Ala725, Phe728, Tyr949, Ser975, Met982, Ala983 and Gln986 (Figure 7C and Supplementary Table 1).

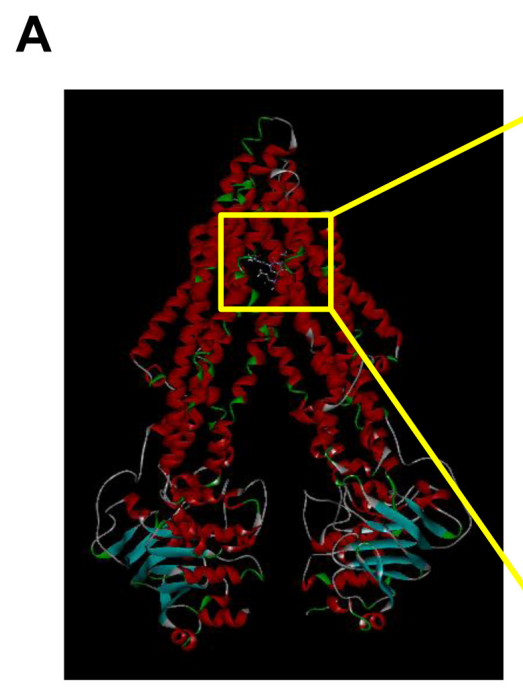

\section{B}

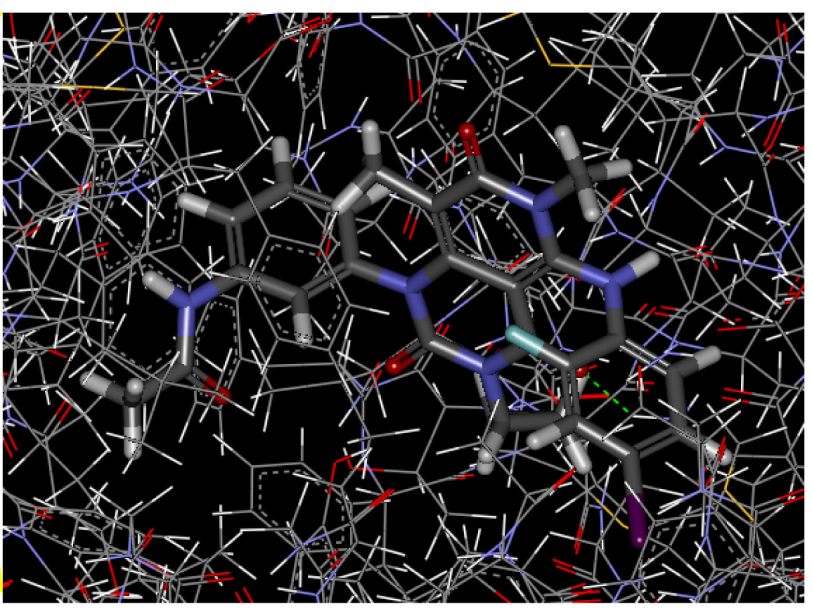

C

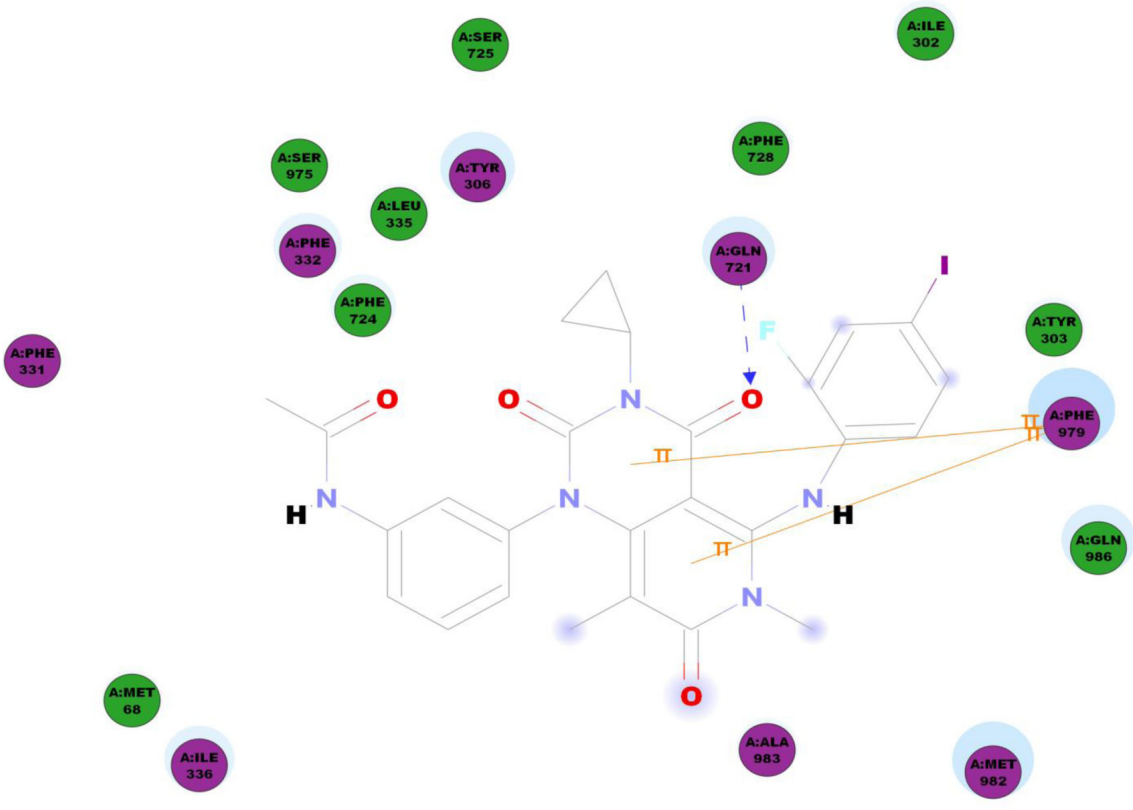

Figure 7: Model for binding of trametinib to ABCB1. The ribbon diagram of 3D structure conformation (A) and the optimal predicted binding mode (B) of trametinib within mouse ABCB1 binding site are shown. Important amino acids are depicted as lines with the atoms colored (carbon, gray; hydrogen, white; nitrogen, blue and oxygen, red), and trametinib is shown as ball and stick model with the atoms colored (carbon, gray; hydrogen, white; nitrogen, blue; oxygen, red; iodine; violet and fluorine; sky-blue). Dotted green line indicates hydrogen bonding interaction. The 2D plane diagram of trametinib-ABCB1 interaction is also presented. Dotted blue line represents the interaction site of trametinib and $\mathrm{ABCB} 1$. 


\section{DISCUSSION}

Targeted therapy currently is one of the major strategies for cancer therapy, which suppresses the growth of cancer cells by inhibiting specific molecular targets required for cancer growth. Small molecular agent is the main category of targeted therapy. Until now, a number of small molecules for cancer targeted therapy were successfully used in clinic, such as BCL-Abl inhibitors imatinib and dasatinib for chronic myelogenous leukemia, epidermal growth factor receptor (EGFR) inhibitors gefitinib and erlotinib for non small cell lung cancer, vascular epidermal growth factor receptor (VEGFR) inhibitors sorafenib and sunitinib for renal cell carcinoma, etc. However, emerging literatures suggest that in addition to mutations of targets, overexpression of $\mathrm{ABC}$ transporters may contribute to the development of resistance to these small molecular agents [21, 22]. We and others have reported that several small molecular agents, including imatinib [23], dasatinib [24], gefitinib [25], erlotinib [26], icotinib [27], sorafenib [28], sunitinib [29], lapatinib [30], apatinib [31], afatinib [32] and so on, are substrates or modulators of ABCB1 or ABCG2. Therefore, when the combination of these small molecules with ABCB1- or ABCG2-substrate agents is applied in the clinic, it should pay attention to the plasma concentrations and tissue distribution of these agents which may be interfered with each other, resulting in unexpected adverse effects. In addition, it is necessary to investigate the interactions of novel small molecules for cancer targeted therapy with $\mathrm{ABC}$ transporters.

In the present study, we showed that trametinib significantly potentiated the effects of vincristine and doxorubicin on inhibition of growth, arrest of cell cycle and induction of apoptosis in cancer cells overexpressed $\mathrm{ABCB} 1$, but not $\mathrm{ABCC} 1$ and $\mathrm{ABCG} 2$. Mechanistically, trametinib potently blocked the drug-efflux activity of $\mathrm{ABCB} 1$ to increase the intracellular accumulation of rhodamine 123 and doxorubicin and stimulates the ATPase of $\mathrm{ABCB} 1$ without alteration of the expression of $\mathrm{ABCB} 1$, suggesting that trametinib may work as the substrate of $\mathrm{ABCB} 1$ to inhibit its function. This is consistent with a recent publication, which demonstrated $\mathrm{ABCB} 1$ plays an important role in limiting brain distribution of trametinib, indicating that trametinib is the substrate of $\mathrm{ABCB} 1$ [33].Consequently, when the combination of trametinib with $\mathrm{ABCB} 1$-substrate agents is adminstrated in vivo, the safety and efficacy of these agents may be affected mutually. In our case, the combination of trametinib with vincristine dramatically inhibited the growth of ABCB1overexpressing xenograft tumors in nude mice without loss of body weight, suggesting that the combination regimen herein is safe and efficient. Additionally, it has been reported that inhibition of the growth of patientderived pancreatic cancer xenografts with trametinib was augmented by combined treatment with lapatinib
[34], or panitumumab and trastuzumabr [35]. Trametinib also enhanced the efficacy of 5-fluorouracil on human colon cancer cells [36], and have synergistic effects with metformin on cell viability and tumor growth in NRAS mutant cancer [37]. In a phase Ib study in 31 patients with advanced solid tumours, administration of trametinib in combination with gemcitabine was feasible, and the addition of trametinib might increase gemcitabineassociated myelosuppression although pharmacokinetics suggested no change in exposures of either drug in combination [38]. However, in the following phase II study in 160 patients with previously untreated metastatic pancreas cancer, the addition of trametinib to gemcitabine did not improve overall survival, progression-free survival, overall response rate and duration of response [39]. Trametinib could safely be given with weekly paclitaxel at the full monotherapy dose with promising progression free and overall survival in the phase I trial in patients with melanoma lacking a V600 BRAF mutation [40]. Concurrent treatment with trametinib and the mTOR inhibitor everolimus resulted in frequent treatmentrelated adverse events, and pharmacodynamic data did not indicate drug-drug interactions between these two agents in the phase Ib trial in 67 patients with advanced solid tumors [41]. In a phase I study in 20 patients with solid tumors and multiple myeloma, trametinib in combination with the AKT inhibitor afuresertib were poorly tolerated at continuous daily dosing, but tolerable at intermittent dosing schedule [42]. In another phase Ib trial in 113 patients with advanced solid tumors, cotreatment with trametinib and PI3K inhibitor buparlisib showed promising antitumor activity for patients with KRAS-mutant ovarian cancer, but long-term tolerability of the combination was challenging due to frequent dose interruptions and reductions for toxicity [43]. Together, the combination of trametinib with other anticancer agents, especially ABCB1-substrate chemotherapeutic agents, need to be further investigated in the either preclinical models or clinical trials.

To sum up, our results shows that trametinib significantly antagonizes ABCB1-mediated cancer MDR in vitro and in vivo by directly blocking the drug-efflux function of $\mathrm{ABCB} 1$, which is supported by the predicted binding mode that showed the hydrophobic interactions of trametinib within the large drug binding cavity of ABCB1. Consequently, our findings may have important implications for use of trametinib in combination therapy for cancer treatment. 


\section{MATERIALS AND METHODS}

\section{Cell culture and reagents}

The ABCB1-overexpressing MDR cancer cells, $\mathrm{KB}_{\mathrm{V} 200}$ and MCF-7/ADR, were generated from human cancer cells $\mathrm{KB}$ and MCF-7 by stepwise exposure to increasing doses of vincristine and doxorubicin, respectively [44]. The ABCC1-overexpressing MDR cancer cells KB-CV60 were derived from KB-31 cells and maintained in medium with $1 \mu \mathrm{g} / \mathrm{mL}$ of cepharanthine and $60 \mathrm{ng} / \mathrm{mL}$ of vincristine [45]. The ABCG2-overexpressing MDR cancer cells S1-M1-80 were established from S1 cells and maintained in the medium with $80 \mu \mathrm{M}$ of mitoxantrone [46]. All cells were cultured in Dulbecco's modified Eagle's medium (DMEM) supplemented with $10 \%$ fetal bovine serum (FBS), penicillin $(100 \mathrm{U} / \mathrm{ml})$ and streptomycin $(100 \mathrm{ng} / \mathrm{ml})$ in a humidified incubator at $37^{\circ} \mathrm{C}$ with $5 \% \mathrm{CO}$. Trametinib was obtained from ApeBio. Vincristine, doxorubicin and cisplatin were ordered from LC Laboratories. Verapamil and rhodamine 123 were purchased from Sigma-Aldrich. Methylthiazolyldiphenyl-tetrazolium bromide (MTT), propidium iodide (PI), hematoxylin and other chemicals were purchased from Sangon Biotech (Shanghai). Pgp-Glo ${ }^{\mathrm{TM}}$ Assay Systems (V3601) was acquired from Promega. Anti-pErk (4370), Anti-Erk (9102), Anti-PARP (9542), Anti-cleaved PARP (5625) and Anti-XIAP (2045) antibodies were from Cell Signaling Technologies. Anticyclin B (61029) and Anti-p21 (554262) antibodies were from BD Biosciences. Anti-ABCB1 (SC-13131) antibody was from Santa Cruz Biotechnology. Anti-GAPDH (KM9002) antibody was from Tianjin Sungene Biotech.

\section{Cell viability assay}

Cells were seeded into a 96-well plate at a density of $5 \times 10^{3}$ cells/well and treated with various concentrations of agents for 72 hours. MTT was added to each well at a final concentration of $0.5 \mathrm{mg} / \mathrm{ml}$. After incubation for 4 hours, formazan crystals were dissolved in $100 \mathrm{ml}$ of DMSO, and absorbance at $570 \mathrm{~nm}$ was measured by plate reader. The concentrations required to inhibit growth by $50 \%\left(\mathrm{IC}_{50}\right)$ were calculated from survival curves as previously described [47].

\section{Cell cycle assay}

Cells were harvested and washed twice with cold phosphate-buffered saline (PBS), then fixed with ice-cold $70 \%$ ethanol for 30 minutes at $4{ }^{\circ} \mathrm{C}$. After centrifugation at $200 \times \mathrm{g}$ for 10 minutes, cells were washed twice with PBS and resuspended with $0.5 \mathrm{ml}$ PBS containing PI $(50 \mu \mathrm{g} /$ $\mathrm{ml}), 0.1 \%$ Triton $\mathrm{X}-100,0.1 \%$ sodium citrate, and DNasefree RNase $(100 \mu \mathrm{g} / \mathrm{ml})$, and detected by FACSCalibur flow cytometer (FCM) after 15 minutes incubation at room temperature in the dark. Fluorescence was measured at an excitation wavelength of $480 \mathrm{~nm}$ through a FL-2filter (585 $\mathrm{nm}$ ). Data were analyzed using ModFit LT 3.0 software.

\section{Apoptosis assay}

Cells were harvested and washed twice with PBS, stained with Annexin V-FITC and propidium iodide (PI) in the binding buffer, and detected by FCM after 15 minutes incubation at room temperature in the dark. Fluorescence was measured at an excitation wave length of $480 \mathrm{~nm}$ through FL-1 $(530 \mathrm{~nm})$ and FL-2 filters (585 $\mathrm{nm})$. The early apoptotic cells (Annexin $\mathrm{V}$ positive only) and late apoptotic cells (Annexin V and PI positive) were quantified with the FlowJO software as previously described [48].

\section{Western blot analysis}

Cells were harvested and lysed in RIPA buffer (1\% NP-40, $0.5 \%$ sodium deoxycholate, $0.1 \%$ SDS, $10 \mathrm{ng} /$ $\mathrm{ml}$ PMSF, $0.03 \%$ aprotinin, $1 \mu \mathrm{M}$ sodium orthovanadate) at $4{ }^{\circ} \mathrm{C}$ for 30 minutes. After centrifuged for 10 minutes at $14,000 \times \mathrm{g}$, supernatants were collected. Protein concentration was quantified using with Bradford assay. Proteins were separated on $12 \%$ SDS-PAGE gels and transferred to polyvinylidene difluoride membranes. Membranes were blocked with 5\% BSA and incubated with the indicated primary antibodies. Corresponding horseradish peroxidase-conjugated secondary antibodies were used against each primary antibody. Proteins were detected using the chemiluminescent detection reagents and films.

\section{Nude mice xenograft tumor assay}

$\mathrm{Balb} / \mathrm{c}$ nude mice were obtained from the Guangdong Medical Laboratory Animal Center and maintained with sterilized food and water. Six female nude mice with 5 weeks old and 18-22 g weight were used for each group. Every mouse was injected subcutaneously of the $\mathrm{KB}_{\mathrm{V} 200}$ cells $\left(3 \times 10^{6}\right.$ in $100 \mu \mathrm{l}$ of DMEM) under the right shoulder. When the subcutaneous tumors were approximately $0.5 \times 0.5 \mathrm{~cm}^{2}$ (two perpendicular diameters) in size, the mice were randomized into four groups and treated with the following regimens: vehicle alone ( $0.9 \%$ saline), vincristine $(0.1 \mathrm{mg} / \mathrm{kg}$, intraperitoneally), trametinib (3 mg/kg, orally), and the combination of vincristine with trametinib every two days. The body weights of the animals and the two perpendicular diameters ( $\mathrm{A}$ and $\mathrm{B}$ ) were recorded every 2 days. The 
tumor volume (V) was calculated as:

$$
\mathrm{V}=\frac{\pi}{6}\left(\frac{\mathrm{A}+\mathrm{B}}{2}\right)^{3}
$$

The mice were anaesthetized after experiment, and tumor tissue was excised from the mice and weighted. The rate of inhibition (IR) was calculated according to the formula:

$$
\mathrm{IR}=\quad 1-\frac{\begin{array}{c}
\text { Mean tumor weight of } \\
\text { Mean tumor weight of } \\
\text { control group }
\end{array}}{\text { exprimental group }^{-}} \times 100 \%
$$

\section{Immunohistochemistry assay}

Immunohistochemistry assay was performed with a microwave-enhanced avidin-biotin stainingmethod as previously described $[49,50]$. Formalin-fixed, paraffinembedded tumor tissue slides were deparaffinized using xylene and graded ethyl alcohol and then rinsed in water. Antigen retrieval was performed by boiling the slides in $0.01 \mathrm{M}$ citrate buffer in a microwave oven for 10 minutes and cooling at room temperature. The slides were then incubated with $0.05 \%$ Triton-X100 in PBS for 5 minutes, followed by sequential treatment in a humidified chamber after quenching endogenous peroxides with $3 \% \mathrm{H}_{2} \mathrm{O}_{2}$ in $\mathrm{MeOH}$ : blocking serum with avidin for 20 minutes, anti-cleaved-PARP antibody overnight at $4{ }^{\circ} \mathrm{C}$, secondary antibody for 20 minutes, hydrogen peroxidase for 15 minutes, and peroxidase substrate solution for 20 minutes at room temperature. The stained slides were then counterstained with hematoxylin and coverslipped. The percentages of C-PARP positive cells were quantified as the average of five fields for each slide.

\section{Rhodamine 123 and doxorubicin accumulation assay}

Cells were seeded into a 6-well plate at a density of $2.5 \times 10^{5}$ cells/well, pre-incubated with or without inhibitors for 1 hour at $37^{\circ} \mathrm{C}$, and incubated with $10 \mu \mathrm{M}$ rhodamine 123 or doxorubicin for another 2 hours at $37^{\circ} \mathrm{C}$. Verapamil was used as the positive inibitor of ABCB1. After washing three times with PBS, cells were analyzed with FCM as previously described [51].

\section{ABCB1 ATPase assay}

The Vi-sensitive ATPase activity of ABCB1 in the membrane vesicles of High Five insect cells was measured as described in protocol. The membrane vesicles $(100 \mu \mathrm{g}$ of protein $/ \mathrm{ml}$ ) were incubated in ATPase assay buffer (50 $\mathrm{mM}$ MES, $\mathrm{pH}$ 6.8, $50 \mathrm{mM} \mathrm{KCl,} 5 \mathrm{mM}$ sodium azide, 2 mM EGTA, 2 mM dithiothreitol, $1 \mathrm{mM}$ ouabain, and 10 $\mathrm{mM} \mathrm{MgCl}_{2}$ ) with or without $0.3 \mathrm{mM}$ vanadate at $37^{\circ} \mathrm{C}$ for 5 minutes, then incubated with different concentrations of drugs at $37^{\circ} \mathrm{C}$ for 3 minutes. The ATPase reaction was incubated by the addition of $5 \mathrm{mM} \mathrm{Mg-ATP}$. After incubating at $37^{\circ} \mathrm{C}$ for 20 minutes, the reactions were stopped by adding $0.1 \mathrm{ml}$ of $5 \% \mathrm{SDS}$ solution. The liberated inorganic phosphate $(\mathrm{Pi})$ was measured as previously described [52].

\section{Docking protocol}

The 3D structure of trametinib was obtained from the software ChemDraw 7.0. The refined crystal structure of mouse ABCB1 in complex with QZ59-RRR (PDB ID: 4M2S) and QZ59-SSS (PDB ID: 4M2T) [53] was obtained from the RCSB Protein Data Bank. Docking experiments were performed with Discovery Studio 3.0. The top-scoring pose ABCB1 complex was then subjected to energy minimization and used for graphical analysis.

\section{Statistical analysis}

A student's t-test was used to compare individual data points among each group. A $P$-value of $<0.05$ was set as the criterion for statistical significance.

\section{ACKNOWLEDGMENTS}

This work was supported by funds from the Chinese National Natural Science Foundation No. 31271444 and No. 81201726 (Z. S.), the Specialized Research Fund for the Doctoral Program of Higher Education No. 20124401120007 (Z. S.), the Guangdong Natural Science Funds for Distinguished Young Scholar No. 2014A030306001 (Z. S.), and the Science and Technology Program of Guangzhou No. 2014J4100009 (Z. S.).

\section{CONFLICTS OF INTEREST}

No, there is no conflict of interest.

\section{REFERENCES}

1. Ozben T. Mechanisms and strategies to overcome multiple drug resistance in cancer. FEBS Lett. 2006; 580:2903-2909.

2. Tsuruo T, Naito M, Tomida A, Fujita N, Mashima T, Sakamoto H, Haga N. Molecular targeting therapy of cancer: drug resistance, apoptosis and survival signal. Cancer Sci. 2003; 94:15-21.

3. Fung KL, Gottesman MM. A synonymous polymorphism in a common MDR1 (ABCB1) haplotype shapes protein function. Biochim Biophys Acta. 2009; 1794:860-871.

4. Chen CJ, Chin JE, Ueda K, Clark DP, Pastan I, Gottesman MM, Roninson IB. Internal duplication and homology with bacterial transport proteins in the mdr1 (P-glycoprotein) 
gene from multidrug-resistant human cells. Cell. 1986; 47:381-389

5. Tatsuta T, Naito M, Oh-hara T, Sugawara I, Tsuruo T. Functional involvement of P-glycoprotein in blood-brain barrier. J Biol Chem. 1992; 267:20383-20391.

6. Thiebaut F, Tsuruo T, Hamada H, Gottesman MM, Pastan I, Willingham MC. Cellular localization of the multidrugresistance gene product P-glycoprotein in normal human tissues. Proc Natl Acad Sci U S A. 1987; 84:7735-7738.

7. Gottesman MM, Ling V. The molecular basis of multidrug resistance in cancer: the early years of P-glycoprotein research. FEBS Lett. 2006; 580:998-1009.

8. Schinkel AH, Jonker JW. Mammalian drug efflux transporters of the ATP binding cassette (ABC) family: an overview. Adv Drug Deliv Rev. 2003; 55:3-29.

9. Ambudkar SV, Dey S, Hrycyna CA, Ramachandra M, Pastan I, Gottesman MM. Biochemical, cellular, and pharmacological aspects of the multidrug transporter. Annu Rev Pharmacol Toxicol. 1999; 39:361-398.

10. Juliano RL, Ling V. A surface glycoprotein modulating drug permeability in Chinese hamster ovary cell mutants. Biochim Biophys Acta. 1976; 455:152-162.

11. Sikic BI, Fisher GA, Lum BL, Halsey J, Beketic-Oreskovic L, Chen G. Modulation and prevention of multidrug resistance by inhibitors of P-glycoprotein. Cancer Chemother Pharmacol. 1997; 40 Suppl:S13-19.

12. Fojo T, Bates S. Strategies for reversing drug resistance. Oncogene. 2003; 22:7512-7523.

13. Abe H, Kikuchi S, Hayakawa K, Iida T, Nagahashi N, Maeda K, Sakamoto J, Matsumoto N, Miura T, Matsumura $\mathrm{K}$, Seki N, Inaba T, Kawasaki H, et al. Discovery of a Highly Potent and Selective MEK Inhibitor: GSK1 120212 (JTP-74057 DMSO Solvate). ACS Med Chem Lett. 2011; 2:320-324.

14. Gilmartin AG, Bleam MR, Groy A, Moss KG, Minthorn EA, Kulkarni SG, Rominger CM, Erskine S, Fisher KE, Yang J, Zappacosta F, Annan R, Sutton D, et al. GSK1120212 (JTP-74057) is an inhibitor of MEK activity and activation with favorable pharmacokinetic properties for sustained in vivo pathway inhibition. Clin Cancer Res. 2011; 17:989-1000.

15. Yamaguchi T, Kakefuda R, Tajima N, Sowa Y, Sakai T. Antitumor activities of JTP-74057 (GSK1120212), a novel MEK1/2 inhibitor, on colorectal cancer cell lines in vitro and in vivo. Int J Oncol. 2011; 39:23-31.

16. Infante JR, Fecher LA, Falchook GS, Nallapareddy S, Gordon MS, Becerra C, DeMarini DJ, Cox DS, Xu Y, Morris SR, Peddareddigari VG, Le NT, Hart L, et al. Safety, pharmacokinetic, pharmacodynamic, and efficacy data for the oral MEK inhibitor trametinib: a phase 1 doseescalation trial. Lancet Oncol. 2012; 13:773-781.

17. Falchook GS, Lewis KD, Infante JR, Gordon MS, Vogelzang NJ, DeMarini DJ, Sun P, Moy C, Szabo SA, Roadcap LT, Peddareddigari VG, Lebowitz PF, Le NT, et al. Activity of the oral MEK inhibitor trametinib in patients with advanced melanoma: a phase 1 dose-escalation trial. Lancet Oncol. 2012; 13:782-789.

18. Kim KB, Kefford R, Pavlick AC, Infante JR, Ribas A, Sosman JA, Fecher LA, Millward M, McArthur GA, Hwu P, Gonzalez R, Ott PA, Long GV, et al. Phase II study of the MEK1/MEK2 inhibitor Trametinib in patients with metastatic BRAF-mutant cutaneous melanoma previously treated with or without a BRAF inhibitor. J Clin Oncol. 2013; 31:482-489.

19. Flaherty KT, Robert C, Hersey P, Nathan P, Garbe C, Milhem M, Demidov LV, Hassel JC, Rutkowski P, Mohr P, Dummer R, Trefzer U, Larkin JM, et al. Improved survival with MEK inhibition in BRAF-mutated melanoma. N Engl J Med. 2012; 367:107-114.

20. Flaherty KT, Infante JR, Daud A, Gonzalez R, Kefford RF, Sosman J, Hamid O, Schuchter L, Cebon J, Ibrahim N, Kudchadkar R, Burris HA, 3rd, Falchook G, et al. Combined BRAF and MEK inhibition in melanoma with BRAF V600 mutations. N Engl J Med. 2012; 367:16941703.

21. Anreddy N, Gupta P, Kathawala RJ, Patel A, Wurpel JN, Chen ZS. Tyrosine kinase inhibitors as reversal agents for ABC transporter mediated drug resistance. Molecules. 2014; 19:13848-13877.

22. Shukla S, Chen ZS, Ambudkar SV. Tyrosine kinase inhibitors as modulators of $\mathrm{ABC}$ transporter-mediated drug resistance. Drug Resist Updat. 2012; 15:70-80.

23. Burger $\mathrm{H}$, Nooter K. Pharmacokinetic resistance to imatinib mesylate: role of the ABC drug pumps ABCG2 (BCRP) and ABCB1 (MDR1) in the oral bioavailability of imatinib. Cell Cycle. 2004; 3:1502-1505.

24. Lagas JS, van Waterschoot RA, van Tilburg VA, Hillebrand MJ, Lankheet N, Rosing H, Beijnen JH, Schinkel AH. Brain accumulation of dasatinib is restricted by $\mathrm{P}$-glycoprotein $(\mathrm{ABCB} 1)$ and breast cancer resistance protein (ABCG2) and can be enhanced by elacridar treatment. Clin Cancer Res. 2009; 15:2344-2351.

25. Leggas M, Panetta JC, Zhuang Y, Schuetz JD, Johnston B, Bai F, Sorrentino B, Zhou S, Houghton PJ, Stewart CF. Gefitinib modulates the function of multiple ATP-binding cassette transporters in vivo. Cancer Res. 2006; 66:48024807.

26. Shi Z, Peng XX, Kim IW, Shukla S, Si QS, Robey RW, Bates SE, Shen T, Ashby CR, Jr., Fu LW, Ambudkar SV, Chen ZS. Erlotinib (Tarceva, OSI-774) antagonizes ATPbinding cassette subfamily B member 1 and ATP-binding cassette subfamily G member 2-mediated drug resistance. Cancer Res. 2007; 67:11012-11020.

27. Wang DS, Patel A, Shukla S, Zhang YK, Wang YJ, Kathawala RJ, Robey RW, Zhang L, Yang DH, Talele TT, Bates SE, Ambudkar SV, Xu RH, et al. Icotinib antagonizes ABCG2-mediated multidrug resistance, but not the pemetrexed resistance mediated by thymidylate synthase and ABCG2. Oncotarget. 2014; 5:4529-4542. 
28. Lagas JS, van Waterschoot RA, Sparidans RW, Wagenaar E, Beijnen JH, Schinkel AH. Breast cancer resistance protein and P-glycoprotein limit sorafenib brain accumulation. Mol Cancer Ther. 2010; 9:319-326.

29. Dai CL, Liang YJ, Wang YS, Tiwari AK, Yan YY, Wang F, Chen ZS, Tong XZ, Fu LW. Sensitization of ABCG2overexpressing cells to conventional chemotherapeutic agent by sunitinib was associated with inhibiting the function of ABCG2. Cancer Lett. 2009; 279:74-83.

30. Dai CL, Tiwari AK, Wu CP, Su XD, Wang SR, Liu DG, Ashby CR, Jr., Huang Y, Robey RW, Liang YJ, Chen LM, Shi CJ, Ambudkar SV, et al. Lapatinib (Tykerb, GW572016) reverses multidrug resistance in cancer cells by inhibiting the activity of ATP-binding cassette subfamily B member 1 and G member 2. Cancer Res. 2008; 68:79057914.

31. Mi YJ, Liang YJ, Huang HB, Zhao HY, Wu CP, Wang F, Tao LY, Zhang CZ, Dai CL, Tiwari AK, Ma XX, To KK, Ambudkar SV, et al. Apatinib (YN968D1) reverses multidrug resistance by inhibiting the efflux function of multiple ATP-binding cassette transporters. Cancer Res. 2010; 70:7981-7991.

32. Wang XK, To KK, Huang LY, Xu JH, Yang K, Wang F, Huang ZC, Ye S, Fu LW. Afatinib circumvents multidrug resistance via dually inhibiting ATP binding cassette subfamily $\mathrm{G}$ member 2 in vitro and in vivo. Oncotarget. 2014; 5:11971-11985.

33. Vaidhyanathan S, Mittapalli RK, Sarkaria JN, Elmquist WF. Factors influencing the CNS distribution of a novel MEK-1/2 inhibitor: implications for combination therapy for melanoma brain metastases. Drug Metab Dispos. 2014; 42:1292-1300.

34. Walters DM, Lindberg JM, Adair SJ, Newhook TE, Cowan CR, Stokes JB, Borgman CA, Stelow EB, Lowrey BT, Chopivsky ME, Gilmer TM, Parsons JT, Bauer TW. Inhibition of the growth of patient-derived pancreatic cancer xenografts with the MEK inhibitor trametinib is augmented by combined treatment with the epidermal growth factor receptor/HER2 inhibitor lapatinib. Neoplasia. 2013; 15:143155.

35. Lindberg JM, Newhook TE, Adair SJ, Walters DM, Kim AJ, Stelow EB, Parsons JT, Bauer TW. Co-treatment with panitumumab and trastuzumab augments response to the MEK inhibitor trametinib in a patient-derived xenograft model of pancreatic cancer. Neoplasia. 2014; 16:562-571.

36. Watanabe M, Sowa Y, Yogosawa M, Sakai T. Novel MEK inhibitor trametinib and other retinoblastoma gene (RB)reactivating agents enhance efficacy of 5-fluorouracil on human colon cancer cells. Cancer Sci. 2013; 104:687-693.

37. Vujic I, Sanlorenzo M, Posch C, Esteve-Puig R, Yen AJ, Kwong A, Tsumura A, Murphy R, Rappersberger K, OrtizUrda S. Metformin and trametinib have synergistic effects on cell viability and tumor growth in NRAS mutant cancer. Oncotarget. 2015; 6:969-978.

38. Infante JR, Papadopoulos KP, Bendell JC, Patnaik A, Burris
HA, 3rd, Rasco D, Jones SF, Smith L, Cox DS, Durante M, Bellew KM, Park JJ, Le NT, et al. A phase 1b study of trametinib, an oral Mitogen-activated protein kinase kinase (MEK) inhibitor, in combination with gemcitabine in advanced solid tumours. Eur J Cancer. 2013; 49:20772085.

39. Infante JR, Somer BG, Park JO, Li CP, Scheulen ME, Kasubhai SM, Oh DY, Liu Y, Redhu S, Steplewski K, Le N. A randomised, double-blind, placebo-controlled trial of trametinib, an oral MEK inhibitor, in combination with gemcitabine for patients with untreated metastatic adenocarcinoma of the pancreas. Eur J Cancer. 2014; 50:2072-2081.

40. Coupe N, Corrie P, Hategan M, Larkin J, Gore M, Gupta A, Wise A, Suter S, Ciria C, Love S, Collins L, Middleton MR. PACMEL: A phase 1 dose escalation trial of trametinib (GSK1120212) in combination with paclitaxel. Eur J Cancer. 2015; 51:359-366.

41. Tolcher AW, Bendell JC, Papadopoulos KP, Burris HA, 3rd, Patnaik A, Jones SF, Rasco D, Cox DS, Durante M, Bellew KM, Park J, Le NT, Infante JR. A phase IB trial of the oral MEK inhibitor trametinib (GSK1120212) in combination with everolimus in patients with advanced solid tumors. Ann Oncol. 2015; 26:58-64.

42. Tolcher AW, Patnaik A, Papadopoulos KP, Rasco DW, Becerra CR, Allred AJ, Orford K, Aktan G, Ferron-Brady G, Ibrahim N, Gauvin J, Motwani M, Cornfeld M. Phase I study of the MEK inhibitor trametinib in combination with the AKT inhibitor afuresertib in patients with solid tumors and multiple myeloma. Cancer Chemother Pharmacol. 2015; 75:183-189.

43. Bedard PL, Tabernero J, Janku F, Wainberg ZA, Paz-Ares L, Vansteenkiste J, Van Cutsem E, Perez-Garcia J, Stathis A, Britten CD, Le N, Carter K, Demanse D, et al. A Phase Ib Dose-Escalation Study of the Oral Pan-PI3K Inhibitor Buparlisib (BKM120) in Combination with the Oral MEK1/2 Inhibitor Trametinib (GSK1120212) in Patients with Selected Advanced Solid Tumors. Clin Cancer Res. 2015; 21:730-738.

44. Shi Z, Liang YJ, Chen ZS, Wang XH, Ding Y, Chen LM, $\mathrm{Fu}$ LW. Overexpression of Survivin and XIAP in MDR cancer cells unrelated to P-glycoprotein. Oncol Rep. 2007; 17:969-976.

45. Taguchi Y, Yoshida A, Takada Y, Komano T, Ueda K. Anti-cancer drugs and glutathione stimulate vanadateinduced trapping of nucleotide in multidrug resistanceassociated protein (MRP). FEBS Lett. 1997; 401:11-14.

46. Robey RW, Medina-Perez WY, Nishiyama K, Lahusen T, Miyake K, Litman T, Senderowicz AM, Ross DD, Bates SE. Overexpression of the ATP-binding cassette halftransporter, ABCG2 (Mxr/BCrp/ABCP1), in flavopiridolresistant human breast cancer cells. Clin Cancer Res. 2001; $7: 145-152$.

47. Shi Z, Tiwari AK, Shukla S, Robey RW, Singh S, Kim IW, Bates SE, Peng X, Abraham I, Ambudkar SV, Talele TT, 
Fu LW, Chen ZS. Sildenafil reverses ABCB1- and ABCG2mediated chemotherapeutic drug resistance. Cancer Res. 2011; 71:3029-3041.

48. Gong LH, Chen XX, Wang H, Jiang QW, Pan SS, Qiu JG, Mei XL, Xue YQ, Qin WM, Zheng FY, Shi Z, Yan XJ. Piperlongumine induces apoptosis and synergizes with cisplatin or paclitaxel in human ovarian cancer cells. Oxid Med Cell Longev. 2014; 2014:906804.

49. Shi Z, Park HR, Du Y, Li Z, Cheng K, Sun SY, Fu H, Khuri FR. Cables 1 complex couples survival signaling to the cell death machinery. Cancer Res. 2015; 75:147-158.

50. Shi Z, Li Z, Li ZJ, Cheng K, Du Y, Fu H, Khuri FR. Cables1 controls $\mathrm{p} 21 / \mathrm{Cip} 1$ protein stability by antagonizing proteasome subunit alpha type 3. Oncogene. 2014; 0.

51. Shi Z, Liang YJ, Chen ZS, Wang XW, Wang XH, Ding Y, Chen LM, Yang XP, Fu LW. Reversal of MDR1/Pglycoprotein-mediated multidrug resistance by vector-based RNA interference in vitro and in vivo. Cancer Biol Ther. 2006; 5:39-47.

52. Shi Z, Parmar S, Peng XX, Shen T, Robey RW, Bates SE, Fu LW, Shao Y, Chen YM, Zang F, Chen ZS. The epidermal growth factor tyrosine kinase inhibitor AG1478 and erlotinib reverse ABCG2-mediated drug resistance. Oncol Rep. 2009; 21:483-489.

53. Li J, Jaimes KF, Aller SG. Refined structures of mouse P-glycoprotein. Protein Sci. 2014; 23:34-46. 